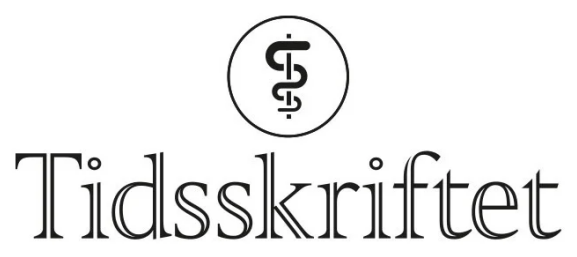

DEN NORSKE LEGEFORENING

\title{
Rettelse: En gravid kvinne med akutte magesmerter
}

RETTELSE

CECILIE FREDVIK TORKILDSEN

RAGNAR KVIE SANDE

KATRINE KIRIAL

MARI EIDE ANDERSEN

LIV CECILIE VESTRHEIM THOMSEN

Tidsskr Nor Legeforen 2021; 141: 559-62.

I Tidsskriftet nr. 9/2021, s. 56o skal det stå: En akutt hypoksisk hendelse defineres som $\mathrm{pH}<$ 7,0 med $B D>12$ samt Apgar $<5$ etter 5 minutter med tegn til moderat/alvorlig encefalopati.

Vi beklager feilen, den er rettet på nett.

Publisert: 7. mai 2021. Tidsskr Nor Legeforen. DOI: 10.4045/tidsskr.21.0380

(C) Tidsskrift for Den norske legeforening 2023. Lastet ned fra tidsskriftet.no 26. april 2023. 